\title{
GENESIS 4:17-24: A CASE-STUDY IN EISEGESIS*
}

\author{
Maarten J. Paul
}

\begin{abstract}
Summary
This article summarises both ancient and modern interpretations of Genesis 4:1724 , paying particular attention to the relatively unknown Jewish exegesis of this pericope. Usually there is a relation between the social and cultural position of the exegete and his positive or negative view of the technical achievements of Cain and his posterity. After a long period of negative interpretation, Calvin is the first to establish another outlook. In this century the discussion between J. Gabriel and C. Westermann reveals many motifs.
\end{abstract}

\section{Introduction}

For those who are interested in the relationship between modern culture and the Bible, a study of Genesis 4:17-24 and a proper understanding of its implications has been regarded as of prime importance. These verses, which describe Cain's building of a city and attribute various inventions to his descendants, have seemed to many exegetes to imply either a positive or a negative evaluation of technological progress. This is true not only of our own century, in which issues such as global warming, depletion of the earth's resources, and various kinds of pollution are so much debated, but of previous centuries as well.

This article aims to examine how commentators over the centuries have treated Genesis 4:17-24, asking how far their views reflect the influence of the cultures to which they belonged. We pay particular attention to early and medieval

\footnotetext{
*This paper was delivered as the Tyndale Old Testament Lecture in Cambridge on 1 July 1993. The author is grateful to Dr P.A. Siebesma and Dr. P.E. Satterthwaite for their perceptive comments.
} 
Jewish commentators, because of the relative obscurity of these exegetes, and follow this with a representative selection from the Christian exegetical traditions.

\section{Overview of Genesis 1-11}

The book of Genesis may be summarised as a theological account of creation and the origin of the people of Israel. A unifying theme appears to be that, in spite of man's sin and apostasy, God remains faithful and provides new starts time and again. When Abel is killed, God continues with Seth. Cain and his descendants are mentioned in passing, yet the story remains focused on the main line proceeding from Seth to Noah. There follows a brief description of Ham, Japheth, and their descendants, after which attention shifts to the line from Shem to Abraham.

The first half of Genesis 4 deals with the contrast between Cain and Abel and ends with Cain's punishment (vv. 1-16). The latter half of the chapter offers a description of Cain's descendants and their inventions (vv. 17-24), which includes Lamech's song of revenge (vv. 23-24). The chapter concludes with two verses referring to Seth and Enosh, and it mentions people calling upon the name of God (vv. 25-26).

Exegetes differ as to whether the structure of Genesis 4, which contrasts Cain's descendants and those of Seth, implies a condemnation of Cain. There is certainly no explicit condemnation of Cain or Lamech, neither is a value judgement expressed on the invention of tents (Jabal), of musical instruments (Jubal) and of metal working (Tubal-Cain).

\section{Jewish Exegesis}

\section{Hellenistic Judaism}

The first two writings discussed here, Jubilees and 1 Enoch, belong to the Pseudepigrapha, writings purposely ascribed to a biblical figure of the past.

Although Jubilees (c. $150 \mathrm{BC}$ ) does not describe the inventions of Cain's sons, it mentions that Cain built a city which he named after his son Enoch. It describes the righteous Enoch, of the line of Seth, as the first 'who learned writing and knowledge and wisdom among the sons of men... and who 
wrote in a book the signs of the heaven according to the order of their months.' He is, therefore, able to calculate the years of jubilee! ${ }^{1}$ This retelling of the Genesis account reflects Jubilees' great interest in chronology. ${ }^{2}$

1 Enoch (second century BC) also does not mention the inventions of Genesis 4, but its exegesis of the first verses of Genesis 6 (1 En. 7:1-9:6) implies a view of them. It relates how two-hundred fallen angels take human wives and teach men magical medicine, incantations, the cutting of roots, and the properties of certain plants; and how the wicked angel Azaz'el instructs men in the art of making swords, knives, shields and breastplates, and other fallen angels teach man the course of the stars and the moon (presumably a reference to astrology). Three good angels inform God what has happened: 'you see what Azaz'el has done; how he has taught all (forms of) oppression upon the earth. And they revealed eternal secrets which are performed in heaven (and which) man learned.' The punishment for this misconduct is the flood. According to 1 Enoch, then, human inventions were heavenly secrets which should not have been revealed. ${ }^{3}$ Man misuses the inventions and is punished. Perhaps the writer of 1 Enoch is here influenced by Genesis 3:22, where God says: 'the man has now become like one of us, knowing good and evil.'

Philo of Alexandria (20 BC-50 AD) devotes a complete book to Cain which is usually referred to by its Latin title: $D e$ Posteritate Caini. According to him, the Genesis account contains numerous historical improbabilities, e.g., that Cain, all alone, built a city for himself. Hence the story should be treated as an allegory:4 Cain builds, not a city, but a philosophy; the buildings of the city are the arguments he uses to resist his

\footnotetext{
$1 J u b$. 4:9-32, esp. v. 17.

${ }^{2}$ However, $J u b$. 11:2-3 perhaps contains indirect exegesis of Gn. 4:17-24: 'And the sons of Noah began fighting in order to take captive and to kill each other... to build fortified cities and walls and towers... and everyone (will act) to do evil and to acquire weapons of battle and to teach their sons war... Ur, the son of Kesed, built the city of Ur of the Chaldees and he named it after his name and his father's name.'

${ }^{3}$ Though a more positive view of astronomy is found at $1 \mathrm{En}$. 72-82, where Enoch is given astronomical and calendrical instruction by the angel Uriel. "In this he follows the Greek Stoics, who used the same method to interpret Homer. See F.W. Farrar, History of Interpretation (1886; repr. Grand Rapids: Baker, 1979) 134-58.
} 
opponents and to fabricate myths; the city's inhabitants are various godless men who build their opinions as towers, the tops of which reach heaven (cf. Gn. 11:4).

Jubal, son of Adah, is mentioned as having invented musical instruments by imitating nature. Zillah was Lamech's second wife. Her name means 'shadow'. Her son Tubal's name means 'completely', according to Philo. It should be taken to mean 'property' or 'riches'. Tubal works metals of which he forges weapons. Philo comments that people go to war to become rich, yet in all this they are merely chasing shadows. ${ }^{5}$ $\mathrm{He}$ is thus critical of Cain's city, of the inventions of Cain's descendants, and, by implication, of much human culture. The invention of music is the only invention which he treats in a neutral way.

Pseudo-Philo's Biblical Antiquities (to be dated between $100 \mathrm{BC}$ and $100 \mathrm{AD}$ ) is a free rendering of history from Abel to David. The treatment in ch. 2 of Adah's second son, Jubal, is striking:

He was the first to teach all kinds of musical instruments. In that time, when those inhabiting the earth began to do evil deeds... God was angry. And he [Jubal] began to play the lyre and the lute and every instrument of sweet song and to corrupt the earth. Now Zillah bore Tubal... this is the Tubal who showed men techniques in using lead and tin and iron and bronze and silver and gold. And then those inhabiting the earth began to make statues and to adore them.

The account links musical instruments with immoral behaviour and metal working with making idols.

According to Flavius Josephus (37-100 AD), the name Cain means 'possession'. Together with his wife he built a city which he named after the land of Nod. The account (Ant. 2:22:1-3) continues:

He also introduced a change in that way of simplicity wherein men lived before; and was the author of measures and weights. And whereas they lived innocently and generously while they knew nothing of such arts, he changed the world into cunning craftiness. He first of all set boundaries about

5Philo, De Posteritate Caini 72-117. 
lands; he built a city, and fortified it with walls, and he compelled his family to come together to it...

Josephus reports Jabal's and Jubal's inventions from a neutral perspective. However, about Tubal he says:

he exceeded all men in strength, and was very expert and famous in martial performances. He procured what tended to the pleasures of the body by that method; and first of all invented the art of making brass.

The descendants of Cain are contrasted with Seth's virtuous offspring, who were 'the inventors of that peculiar sort of wisdom which is concerned with the heavenly bodies, and their order.'

How did Josephus arrive at this interpretation? Cain's introduction of weights and measures is probably derived by linking his name with the Hebrew words qānâ ('obtain') and qāneh ('reed', hence 'measuring rod, measure'). 6 In linking Tubal's invention of metal-working to warfare Josephus seems to follow Philo. Similarly, he agrees with Jubilees in attributing the knowledge of the stars to Enoch, Seth's descendant. From this period come many Jewish works that depict the Israelite ancestors as having a superior civilisation, and thus attempt to counter anti-Semitic propaganda. ${ }^{7}$

\section{Jewish Haggada}

In Jewish belief the Torah or Pentateuch has a central position. The Torah can be read as a historical account, but that is not the whole meaning. Each narrative has also a meaning for the reader or listener in later times:

The Torah according to the traditional view, is no mere literal recording of historical events, a chronicle of facts, scientific or otherwise, but a highly selective manual of moral and religious lessons which are illustrated in the main

${ }^{6} \mathrm{~L}$. Ginsberg, The Legends of the Jews (7 parts, 1909-38; repr. Philadelphia: The Jewish Publication Society of America, 1967-69) part 5, 144-145.

${ }^{7}$ G. Vermes, 'Bible and Midrash: Early Old Testament Exegesis' in P.R. Ackroyd and C.F. Evans (eds.), The Cambridge History of the Bible, Vol. I (Cambridge: CUP, 1970) 227-228. 
developments in the universe since its creation seen from the vantage point of its Divine Author. 8

At Cain's birth, Eve cries out (according to the usual translation of Gn. 4:1): 'I have gotten a man with the help of the Lord'. The Hebrew for 'I have gotten' is qānit tî: the text suggests a link between Eve's cry and the name 'Cain' (Hebrew qayin). Midrash Haggadol introduces a different word-play: Eve prophesies that Cain will come to nothing (Hebrew keّe ayin). ${ }^{9}$

Genesis 4:17 mentions Cain's city-building activities. Midrash Aggadat Bereshit (= the narrative midrash of the book Genesis) ${ }^{10}$ adduces that Cain built a city because he had heard that his descendants would be exterminated after seven generations. By naming the city after his son he hoped to ensure the continued existence of his son's name.

Bereshit Rabbah (= Genesis Rabbah) also criticises Cain's attitude. In this context Psalm 49:12 is quoted: 'Their inward thought is, that their houses shall continue for ever... they call their lands after their own names'.11 J. Neusner interprets this section in relation to the date of its composition (400-450 AD):

Coming to closure at the time of the building of Constantinople, the document at hand cannot have been more direct. Gentiles (including Christians) will not enjoy the resurrection of the dead, so they have to memorialise themselves by building cities and putting their names on

${ }^{8} \mathrm{~N}$. Leibowitz, Studies in Bereshit (Genesis) in the Context of Ancient and Modern Jewish Bible Commentary (ET; 3rd ed. Jerusalem: World Zionist Organization, 1976) xxx. Just as the Torah contains both laws and statutes, and edifying stories, we find both halakhic and haggadic exposition: legal exposition and homily. The literal meaning must not be explained away by an allegorical or mystical interpretation; it always remains basic. But alongside it, the homiletical, figurative, meaning can be deduced from the text as a legitimate additional meaning. See E.I.J. Rosenthal, 'The Study of the Bible in Medieval Judaism' in G.H.W. Lampe (ed.), The Cambridge History of the Bible, Vol. II (Cambridge: CUP, 1969) 253.

${ }^{9}$ See M.M. Kasher, Encyclopedia of Biblical Interpretation: a Millennial Anthology (9 vols.; New York: American Biblical Encyclopedia Society, 1953-79), Vol. I, 145; cf. Ginzberg, Legends, Vol. V, 135 for additional explanations.

${ }^{10}$ The Aggedat Bereshit dates back from the tenth century and contains a number of anti-Christian polemics. See Encyclopaedia Judaica, Vol. II, 366.

${ }^{11}$ Midrash Rabbah, ch. 23. 
them. Israel does not have to build cities of that kind, because it will enjoy the resurrection of the dead'. ${ }^{12}$

Later, Bereshit Rabbah discusses Jabal. He is described as the father of those living in tents and possessing cattle. With a pun on 'cattle' (Hebrew hammiqneh), Ezekiel 8:3 is quoted: 'Formerly they used to provoke the Holy One, blessed be He, in secret [= "in their tents"], but subsequently they provoked Him openly, as it is written: The image of jealousy, which provoked to jealousy (Hebrew hammaqneh)'. Tubal-Cain's inventions are also negatively assessed: 'This man perfected (Hebrew tibbēl) Cain's sin: Cain slew, yet lacked the weapons for slaying, whereas he was the forger of every cutting instrument'.

\section{Medieval Jewish Exegesis}

The work of Nachmanides (1194-1270), Talmudist, Bible exegete and physician, is characterised by his open evaluation of traditional views which he often criticises.13 At 4:17, he favours the translation 'and he was building a city', which, in his view, indicates that Cain was building the city all his days because his works were cursed. Thus he would build a little with effort and toil, and then move and wander off from that place and return there and build a little more, but he would not prosper in his ways. Nachmanides says about Tubal-Cain that he was 'the forger of all cutters in copper and iron', yet it is better to read 'the forger and cutters in all copper and iron'. He says of Lamech and his sons:

It appears to me that Lamech was a very wise man in every craft, and he taught his eldest son (Jabal) the business of pasturing according to the nature of the cattle. To the second son (Jubal) he taught the art of music, and he taught the third one (Tubal-Cain) to forge metals and to make swords, spears, javelins, and all instruments of war. His wives were then afraid that he might be punished because he brought the

\footnotetext{
12J. Neusner, Genesis Rabbah, the Judaic Commentary to the Book of Genesis, A New American Translation, Vol. I (Atlanta: Scholars Press, 1985) 255-56. Constantinople was, of course, named after the Christian emperor Constantine.

${ }^{13}$ Encyclopaedia Judaica, Vol. XII, 774-782. N. Kravitz, 3000 years of Hebrew literature, from the earliest time through the 20th century (London: W.H. Allen 1973) 295-97.
} 
sword and murder into the world... But he (Lamech) told them: 'I did not slay a man by wounds, nor a child by bruises, ${ }^{14}$ as Cain did, and God will not punish me. Instead, He will guard me from being killed more so than Cain.' He (Lamech) mentioned this in order to say that man cannot kill only with the sword and javelin; death caused by wounds and bruises is a worse death than by the sword. Therefore, the sword is not the cause of murder, and there is no sin upon him who made it. ${ }^{15}$

Nachmanides suggests that the inventions are highly valued. Lamech is even praised as a wise man! Perhaps he views Lamech as the man who carries out Genesis 1:28. His explanation of that verse is: 'Subdue the earth, that is: to be lord over the earth, to do his will with the creatures in it, build, uproot, plant, mine copper from its mountains'.16

The Chronicles of Jerahmeel (c. 1150) provide the following comments on the inventions of Lamech's sons:

$\mathrm{He}$ (= Jabal) discovered the work appertaining to shepherds... He also invented the locks which are made to prevent thieves entering the house... At this time the inhabitants of the earth began to commit violence, to defile each other, and kindle the anger of the Lord. They began to sing with the harp and the reed-pipe, and to sport with all kinds of song corrupting the earth. Thus Jubal discovered the science of music, whence arose all the tunes for the above two instruments. This art is very great... And Zillah bare Tubal-Cain, who forged all the iron implements of war, and was an artificer in all kinds of iron work. He also discovered the art of joining lead and iron together, in order to temper the iron and to make the blade sharper. He also invented the pincers, the hammer, and the axe, and other instruments of iron. Tubal was a worker in all kinds of tin and lead, iron and copper, silver and gold.

\footnotetext{
${ }^{14}$ Lamech's statement is read as a question and therefore treated as a negation. Targum Onkelos preceded Nachmanides in this respect. See M. Aberbach and B. Grossfeld, Targum Onkelos to Genesis: A Critical Analysis Together With An English Translation of the Text (Denver: KTAV, 1982) 4445.

${ }^{15}$ Ramban (Nachmanides), Commentary on the Torah, Genesis, tr. Ch.B. Chavel (New York: Shilo, 1971) 92-96.

${ }^{16}$ Cf. N. Leibowitz, Don Isaac Abravanel, 22.
} 
Emphasis is here placed on the sheer amount of inventions rather than on their harmful application. Although music is misused, the Chronicles state that 'this art is very great.' No value judgement is expressed on the inventions of Jabal and Tubal-Cain. ${ }^{17}$

\section{Abravanel}

The Spanish exegete Don Isaac Abravanel (1437-1508) expressed severe criticism of inventions and civilisation. ${ }^{18} \mathrm{He}$ felt that God gave man all he needed in the Garden of Eden.

There was no need for any artificial effort to obtain them, and man's mind was free from any worry over their acquisition. He could fully concentrate upon the elevation of his soul through constant contemplation of God and His works, and fulfil the purpose for which he was created. ${ }^{19}$

According to Abravanel, the source of sin is man's dissatisfaction with the natural things God has prepared for him and his development of a passion for the abnormal and unnatural. The three sons of Adam, Cain, Abel, and Seth, represent three possible ways of life, the animal, the political and the rational. Seth represents the class of men who understand that the real purpose of man's life is the worship of God and the attainment of knowledge. Abel represents a somewhat baser ambition for leadership and honour, but his life-style is still relatively 'natural' in that he does not engage in agriculture. Cain symbolises the lowest level, a life devoted to passions and to the arts which satisfy these passions. Attached to matter, to earth, he became a tiller of the soil. He was involved in artificial pursuits: for the farmer who ploughs to sow, robs the soil. Interested in artificial production, he built a city called Enoch, meaning 'education', where he taught his sons the different crafts and luxurious arts, including music

\footnotetext{
17The author of this collection of old Jewish and non-Jewish traditions is Jerahmeel ben Solomon: see Kasher, Encyclopedia, 161. According to Josephus Seth's descendants engraved the musical art on two pillars (Ant., $1: 2: 3)$

18B. Netanyahu, Don Isaac Abravanel: Statesman and Philosopher (3rd. ed.; Philadelphia: The Jewish Publication society of America, 1972).

${ }^{19}$ Commentary on Genesis, 2:5.
} 
and the forging of metals. 20 The tendency towards urban life, initiated by Cain and continued after the flood by Nimrod (Gn. 10:8-12) is thus a tendency towards the artificial, which reaches its extreme point in the generation of the tower of Babel $(\mathrm{Gn}$. 11:1-9).

This point of view prompts the question why the Torah does not forbid all these types of labour. Abravanel answers:

When God saw that humanity was already sunk in the craving for artificiality and irremediably given over to such activity $\mathrm{He}$ did not forbid them His people, but commanded them to purify them, to use them in an upright manner and not to abuse them. ${ }^{21}$

According to Leibowitz, Abravanel's view does not represent classical Judaism, and is to be explained with regard to tragic events in his own life: he was driven out of Portugal and Spain and had had many negative experiences in court circles. ${ }^{22}$ Against Abravenel's view that the very aspiration to organise a political society is evil, a more positive assessment is offered by his contemporary Isaac Arama (1420-94):23

That generation [of Gn. 11], being united by one common language and sharing the same ideas became unanimously convinced that the aim of their existence was a political society. Their sin was not in trying to achieve this but in regarding it as an end in itself rather than as a means to a still greater end - spiritual well-being. ${ }^{24}$

Abravanel's threefold division into the animal, the political and the rational seems to have been taken over from Aristotle; 25 and

\footnotetext{
20Netanyahu, Don Isaac Abravanel, 136-42.

${ }^{21}$ Commentary on Genesis, 11:1.

${ }^{22}$ Leibowitz, Studies in Bereshit, 94-95.

${ }^{23}$ Leibowitz, Studies in Bereshit, 96.

${ }^{24}$ Akedat Yitzhak, ch. 14.

${ }^{25}$ Aristotle, Ethica Nicomachea 1:3 (1095b, 17ff). Netanyahu, Don Isaac Abravanel, 302, n. 73; cf. Encyclopaedia Migra'it, Vol. VIII, 714-22 for the interaction between Jewish and Christian scholars.
} 
Seneca anticipated his rejection of civilisation and preference for the natural. ${ }^{26}$

\section{Christian Exegesis}

\section{Patristic Exegesis}

The church father Augustine (354-430) wrote his work De Civitate Dei in response to pagan accusations that the Christians were guilty with regard to the fall of the city of Rome in 410 . He divides mankind into two groups, of which one lives an 'earthly' existence and the other a 'heavenly' existence. Metaphorically, he calls them two states, i.e., two types of society. The two states are represented by Adam and Eve's first sons, Cain and Abel: Cain established an earthly state; Abel, reflecting the fact that citizens of the heavenly state are pilgrims on earth, did not. Augustine's detailed exegesis of Genesis 4:1724 supports this overarching distinction. Cain names the city after his son: Augustine concludes that they want to have a name in this world; Seth, by contrast, means 'resurrection'. In the genealogy from Seth to Noah no women are mentioned as mothers. In contrast, the genealogy of Cain's descendants does include women's names: Adah, Zillah and Naamah, indicating that the fleshly lusts play an important role among the worldly inhabitants. Lamech is the seventh from Adam. He has four children so that Naamah becomes the eleventh. Eleven exceeds ten. Since this violates the Decalogue it is $\sin .27$

The Venerable Bede (d. 835) also attributes a negative value to the inventions of Cain's descendants. Bede explains the name Enoch as 'dedication': Cain builds a city and dedicates it

\footnotetext{
${ }^{26}$ Letters to Lucilius, 90: 'The roof of the free man consisted then of thatch, under marble and gold now lives a human race consisting of slaves... Wisdom resides higher and does not teach the hands anything... She does not create weapons, no walls, no implements of war; she sides with peace and calls mankind to unity.'

27De Civitate Dei XV, chs. 1, 17 and 20. Many contemporaries of Augustine, pagan and Christian alike, attributed the greatest significance to numerology; see G. Bonner, 'Augustine as biblical scholar', in The Cambridge History of the Bible, Vol. I, 559-60.
} 
immediately, for the rejected ones seek pleasure in this life. The sons of Lamech invent all kinds of things for the ease and embellishment of their life (ad cultum). In contrast, Abel and Seth lived as pilgrims on earth in simplicity. Abel was a shepherd, but did not make tents for his family. However, Bede takes account of the fact that later generations of Israelites do use such inventions: while they may have originated with the sons of the curse, God later made them available for general use. The elect, however, use them in a distinctive way: although the Patriarchs lived in tents, they lived as sojourners on earth, quite distinct from those who lived in cities as the inhabitants of this world; the psalmists used musical instruments, yet only in God's honour; among the people of God there were men skilled 'in all work of copper and iron', yet they used their skills for the tabernacle. ${ }^{28}$

\section{Luther and Calvin}

The exegetical approach of Luther (1483-1546) agrees with Augustine where Cain's building of a city is concerned. According to Luther, Cain behaves as an 'inhabitant of the earth', for if all people were Christians there would be no need for a worldly sword or protection. Those who stayed with Adam did not build a city and did not think of protecting themselves, for their walk was in heaven (Heb. 11). However, Cain built a city not only out of fear and in self-defence, but also because of his desire to rule.

In Luther's view, Jabal lived for food and wealth, whereas Adam and Eve were not concerned about wealth at all. Tubal-Cain, a master craftsman, worked metal and became a warrior. He was the first man who wanted to subdue people and lands with the sword and he desired to rule over them with iron. The third son, Jubal, promoted dancing and desired to have good days, lust, and peace. ${ }^{29}$

\footnotetext{
28Bede, In Genesim, II, iv, 17-22 (ed. CCSL, Vol. 118a, 86-89) and Hexaemeron, II (ed. Migne, Patr. Lat, Vol. 91, 72-76).

${ }^{29}$ Luther, Predigten über das erste Buch Mose gehalten 1523 und 1524, published later in a Latin and German edition: In Genesin Mosi librum sanctissimum Declamationes (1527) and Ueber das erste Buch Mose, Predigten sampt einer Unterricht, wie Moses zu leren ist (1527).
} 
According to Calvin (1509-64), it appears to be against God's judgement that Cain builds a city. ${ }^{30}$ Yet it is probable that man, due to a bad conscience, did not feel at ease within the walls of his own house anymore, so that he devised a new kind of fortification. Adam and the others lived in the field because they were less afraid, but Cain's motives were fear and pride. The latter is evident from the city's name. Calvin's application for us is that, although we are allowed to live under the protection of fortifications of cities and castles, we should mark their first beginnings in order that we may know our ailments by means of the medicines against them.

In Calvin's opinion, Moses reports that some good was mixed with the evil caused by Cain's descendants. Calvin regards the invention of arts and other things pertaining to general use and comfort as desirable gifts of God or praiseworthy virtues. Nevertheless, he finds it surprising that the people which deviated most from the original virtues are credited with these inventions. He observes that

the experience of all ages shows that the civilisation of godless people has been influenced by rays of divine light. Today, we see that magnificent gifts of the Spirit have been distributed among all mankind. Even the fine arts and sciences of godless people have become ours, including astronomy, and other areas of philosophy, medicine and political science. No doubt, God blessed them so mildly with excellent gifts that they would have less of an excuse for their godlessness. Let us, however, in such a way admire the treasures of grace which God pours out over them that we may deem the grace of the new birth as more excellent.

Calvin continues by stating that although the invention of the zither and other such musical instruments serves entertainment and pleasure rather than necessary use, these instruments should not be regarded as totally superfluous. However, enjoyment must be rejected if it is not related to the fear of God or the common purpose of human society. The art of music is

30J. Calvin, A Commentary on Genesis (ET 1847; repr. London: Banner of Truth, 1965). 
such that it can be made to serve duty and piety and that it can be to peoples' benefit.

In the Institutio Calvin more generally addresses the issues under discussion. Pagan poets have confessed that philosophy, law, and all good arts were inventions of the gods. In Calvin's view, this shows that those people whom the Scriptures refer to as 'natural men' in their research of lower things have been quite discerning and rich in insight. If the Lord wants to help us by means of the toil and the service of godless people in the natural sciences, the art of reasoning, mathematics, and other disciplines of that nature-let us use those gifts so that we do not risk being judged for our laziness in not using them. 31

It is remarkable that Calvin speaks in such positive terms about these inventions. Why does he do so, when his theology is permeated by the notion of man being a sojourner? Perhaps we should attribute this to his humanistic education. Yet his desire systematically to think through all kinds of issues is also an important factor.

\section{Delitzsch and Kuyper}

This cautiously positive attitude to culture recurs in the nineteenth-century commentator, F. Delitzsch (1813-90). Delitzsch comments:

Cultural progress in antediluvian days does not keep pace with religious progress. Cultural progress overtakes religious progress and treats it as its enemy. Nonetheless, it has its right of existence and each attainment of the natural world's development eventually becomes the property of God's Kingdom, having stood the test of a purification and glorification process. This especially applies to music, the daughter of heaven descended to earth. 32

This is further developed in the work of A. Kuyper (1837-1920), who summarises the development of the human race:

${ }^{31}$ Calvin, Institutio, Book II, ch. ii, par. 12-18.

32F. Delitzsch, Neuer Commentar über die Genesis (5th ed.; Leipzig: Dörffling \& Franke, 1887) 124-29. 
1. God's common grace is reflected in the history of the nations, first in Babylon, then in Egypt, later in Greece and Rome. These nations each successively exercise the talents with which God has endowed the human race, and bring them to a peak of brilliance. Yet sin continues to work in all this. When the development among one nation dies due to sin, God transfers it to another people that is less corrupted and hence it continues, century after century.

2. A different development occurs in Israel. This does not mean that common grace did not apply in Israel but that in Israel common grace and particular grace merged. Israel's work reaches its climax in the birth of Christ.

3. In the Christian era, common grace and particular grace continue to merge: the Christian church displays the fruits of both particular grace and common grace. The nations, which remain Jewish or pagan (or at a later date become Islamic) may exercise a temporary influence. Yet eventually, only the Christian nations bear the real development of the human race. They control the world. This is where the highest development occurs in the field of trade and industry, of science and art, intertwined with the richest display of the power of grace from the eternal Kingdom. The life of common grace has never more fully been developed than in the Christian nations. 33

Kuyper expressed these enthusiastic opinions at the turn of the century, at time when the Christian nations in Europe and America were at what seemed to be a peak of their achievement, and before the devastation of two World Wars.

\section{Gabriel, Westermann, Ellul}

We turn to three theologians of the recent past. J. Gabriel discusses the etymology of the names of Cain's descendants (concluding that many names in themselves may be explained both positively as well as negatively), and suggests that, though

\footnotetext{
${ }^{33} \mathrm{Abr}$. Kuyper, De Gemeene Gratie (2nd ed., no publication date; c. 1910), Vol. I, 284-87 and 502-04, Vol. II, 552-53 and Vol. III, 497-98. See also M.J. Paul, 'Cultuurmandaat en vreemdelingschap' in Redevoeringen Evangelische Hogeschool (Amersfoort: EH, 1989) 15-36.
} 
the narrative contains no explicit evaluation, it implicitly condemns Cain's building of a city and Lamech's bigamy.

In Gabriel's view, Genesis 4 does not focus on the growth of material culture. The Bible is geared to religious interests. However, it may be that the genealogy makes a distinction between the sons of Lamech's two wives, treating Lamech's second wife as illegitimate: the aspects of human culture associated with Adah's children are not condemned, and may be beneficial; the culture associated with Zillah's children leads, by implication, to physical and moral corruption. 34

C. Westermann contests Gabriel's view that the Bible is only interested in religious matters. ${ }^{35}$ God ordained man's labour (2:15 and 3:23) and thereby paved the way for the developments in 4:17-24. According to Westermann, the Jahwist regards cultural history as a necessary ingredient of human history, anchored in God's mandate. Therefore, it is legitimate for people created by God to strive to go forwards. In the Jahwist's view, Israel is merely an inheritor of the cultural developments of preceding generations. Westermann also draws into his argument texts such as Deuteronomy 6:10 and Isaiah 2:4/ Micah 4:3. According to Deuteronomy 6:10 Israel may possess 'large and flourishing cities which you did not build' in Canaan, which implies that Israel did not regard the establishment of a city and urban culture as something intrinsically negative; and the promise in Isaiah 2:4 and Micah 4:3 that in the end-times swords will be beaten into ploughshares suggests that technology is in essence a positive development, no matter how much it is abused. These passages, indeed, presuppose the invention (in itself positive) of the art of forging. God's blessing enables people to invent.

On the basis of the Old Testament's positive attitude towards culture, Westermann concludes that theology must become more involved in the natural sciences. The acknowledgement of the positive value of technology provides theology with the authority to address the danger which people

34J. Gabriel, 'Die Kainitengenealogie Gn 4,17-24', Biblica 40 (1959) 409-27.

${ }^{35} \mathrm{C}$. Westermann, Genesis 1-11 (Neukirchen-Vluyn: Neukirchener, 1974) 438-67. 
face from a highly-developed technology serving the lust for power of an individual or a group (4:23-24).

Westermann appears to have overstated his case in arguing that cultural development is completely legitimised by God's order to build and to keep the earth. Westermann's perspective does not take sufficient account of the effects of sin. Moreover, he barely takes the context into consideration, perhaps because of his form-critical approach, which tends to treat units of text in isolation. Gabriel rightly bases his view on larger textual units and on narrative technique. Though Deuteronomy 6:10 states that Israel may possess existing cities, it hardly suggests this is an entirely positive development, for the context warns against the danger that people might forget God. Possessions may cause man to become too independent from God. ${ }^{36}$ Similarly, Westermann's treatment of the Isaiah and Micah passages seems to beg the question. Westermann tends to treat culture as a neutral entity. Yet culture always has underlying aims; either those of the idols (in ancient or modern guise) or those of God. It is basic to the viewpoint of Genesis 4 that religion and culture are interwoven.

In contrast to Westermann, J. Ellul has a strongly negative attitude toward technology when it becomes a mere 'technique', bringing environmental pollution in its wake. $\mathrm{He}$ opposes a theology of culture and historical positivism, and lays weight on the fact that the first time the Bible speaks clearly about technology is in the account of Cain. For Adam after his sin and for Cain it is necessary to invent: 'He must invent, and these means will no longer be those of communion, but means of force, laceration, utilisation, and exploitation. This is where Technique stands.' ${ }^{\prime 37}$ However, the biblical account is

${ }^{36}$ See Dt. 11:10-15 for the same theme concerning the water supply. $C f$. G. Wallis, 'Die Stadt in den Ueberlieferungen der Genesis', ZAW 78 (1966) 133-48 and F.S. Frick, The City in Ancient Israel (Missoula: Scholars Press, 1977) 205-07.

37J. Ellul, 'Technique and the Opening Chapters of Genesis' in C. Mitcham and J. Grote (eds.), Theology and Technology: Essays in Christian Analysis and Exegesis (Lanham: University Press of America, 1984) 123-37, esp. 133. 
'not a judgement against science and progress but against what they signify for man in his situation of rupture with God'.38

\section{Evaluation}

It is clear from the above brief survey that all kinds of hermeneutical issues come into play in the exegesis of Genesis $4: 17-24$. The interpretations reviewed above are clearly influenced by differing views of culture and technology. One of the advantages of studying ancient as well as modern commentators is that it highlights the unconscious biases which can influence exegesis in any age. 39

Jewish exegesis may seem to us somewhat free in the way it draws links between different parts of the Bible. Yet we may learn from these exegetes' concern to grasp the essence of the story, evident in their (mainly negative) assessments of culture and technology in Genesis 4: culture and technology are not regarded as being value-free, but are judged by their origins and use in a certain historical context.

From the brief overview of the Christian tradition, it is evident that Augustine's negative judgement carried much weight. Calvin is the first who praises the sciences. Abraham Kuyper follows his example, though he displays a characteristically nineteenth-century optimism concerning technological progress. For some twentieth-century exegetes, by contrast, the destruction wrought in both World Wars epitomises the negative effects of technology. In our own era, there is a tendency to suggest that there may be a demonic aspect to the development of science and technology.

It is also important whether the exegete deals with scriptural passages in isolation or whether he takes the context into account. If we study the literary structure of the first chapters of Genesis, it cannot be a coincidence that the

38J. Ellul, 'Cain, the Theologian of 1969', Katallagete, 1969, 4-7. See further his The Meaning of the City (Michigan: Eerdmans, 1970).

${ }^{39}$ In my thesis Het Archimedisch punt van de Pentateuchkritiek ('sGravenhage: Boekencentrum, 1988) I studied the history of exegesis and the presuppositions with regard to the exegesis of the reforms of Josiah (2 Ki. 22-23). 
important inventions are recorded for Cain's descendants whereas none are mentioned in relation to Seth's posterity. The manner in which the story is told indicates a correlation between man's rejection of serving God and the introduction of technology. Among Cain's descendants a progressive development can be observed in which, for instance, Lamech's words surpass those of his forefather Cain. The inventions are located within a corrupting development. They express man's need for independence from God which became evident as early as Genesis 3 in the lives of Adam and Eve. Similarly, Genesis 4 ends with the birth of Seth, noting that 'at that time, men begin to call upon the name of the Lord' (v. 26). Genesis 4:17-26 marks a contrast between both lines of descent: Cain's descendants are dedicated to technological progress yet reject God, but Seth's descendants call upon the name of the Lord.

Moreover, it is important that we study the book of Genesis in the light of the whole Old Testament, the canon of which it now forms a part. When we do this, we find that cities can be valued in a positive sense. Israel receives cities from the land of Canaan. The city of Jerusalem is the city where God Himself desires to dwell. Civilisation as such is not rejected. Similarly, music in the Old Testament is usually positively regarded, being used in the worship in the tabernacle and the temple. In Psalm 150 all kinds of musical instruments used to praise God are mentioned. The origins of such inventions may be surrounded by negative implications, yet a positive use is possible. I can sympathise with the approach of the Venerable Bede: that which man intended for evil purposes, God may put to good use ( $c f$. Gn. 50:20). This implies that we must not judge inventions only by their origins, for they may be used for good or for evil. The invention of the printing press was dubbed a step towards heaven as well as a step towards hell.

One of the implications of Genesis 4 is that we should examine the spiritual roots of the various existing inventions and of those goals which science is yet trying to achieve. Is their aim to honour God or to promote man's independence from God? Genesis 4 traces a connection between religion and culture, between faith and technology. People in our culture often deny, or try to break, that connection. The modern 
exegete of Genesis 4 must insist that the connection is still there, and that it is of enormous significance for our own involvement in science and in society. 